\title{
Controlling the Airwaves: Incumbency Advantage and Community Radio in Brazil
}

\author{
Taylor C. Boas Boston University \\ F. Daniel Hidalgo University of California, Berkeley
}

\begin{abstract}
Direct influence over communication media is a potent resource during electoral campaigns, and politicians have an incentive to gain control of the airwaves to advance their careers. In this article, we use data on community radio license applications in Brazil to identify both the causal effect of incumbency on politicians' ability to control the media and the causal effect of media control on their future electoral prospects. Using a regression discontinuity design, we compare city council candidates who barely won or barely lost an election, showing that incumbency more than doubles the probability of an application's approval by the Ministry of Communications. Next, using genetic matching, we compare candidates who acquired community radio licenses before an election to similar politicians who did not, showing that a radio station substantially increases one's vote share and probability of victory. These findings demonstrate that media control helps entrench local political power in Brazil.
\end{abstract}

I ndependent mass media are central to the functioning of modern democracy, both because they give candidates a chance to campaign on a level playing field and because they can hold politicians accountable to the public once in office. Consequently, control of the media by politicians is typically seen as infringing upon the quality of democracy or the existence of democracy itself (e.g., Coppedge and Reinicke 1990; Diamond and Morlino 2005). Most attention to the phenomenon has focused on cases where powerful national executives dominate the airwaves through business deals or brute force, such as Italy under Silvio Berlusconi or Peru under Alberto Fujimori.

This article examines a less heralded but equally problematic form of political control of the media-the ability of Brazilian municipal politicians to gain government approval for community radio stations whose coverage they can influence during future electoral campaigns. In contrast to heavy-handed media control by national executives, local political bosses in Brazil are able to dominate the airwaves by working within the democratic system itself, through exchanges of political favors. In this sense, political control of local media is endemic to the functioning of Brazilian democracy. It also has the potential to alter electoral results. For reasons discussed below, municipal elections in Brazil lead to a particularly strong expectation of media effects and other electoral benefits for candidates who control community radio stations. The result is a vicious circle in which political power can become increasingly entrenched over time.

In this article, we first demonstrate that political control of community radio constitutes a "spoil of office" in Brazil because incumbents are disproportionately able to achieve it. Using a regression discontinuity (RD) design, we compare politicians who barely won election as city council member in 2000 or 2004 to those who barely lost, examining the fate of postelectoral radio license applications among each group. We find that incumbency has a large positive effect on the probability of an application's approval by the Ministry of Communications.

Taylor C. Boas is Assistant Professor of Political Science, Boston University, 232 Bay State Rd., Boston, MA 02215 (tboas@bu.edu). F. Daniel Hidalgo is a Ph.D. candidate in Political Science, University of California, Berkeley, 210 Barrows Hall \#1950, Berkeley, CA 94720 (fdhidalgo@gmail.com).

For helpful comments, we are grateful to Ben Allen, Thad Dunning, Eduardo Gómez, Francesca Jensenius, Jody LaPorte, Scott Mainwaring, Elizabeth Levy Paluck, Neal Richardson, David Samuels, Terri Towner, four anonymous reviewers, and seminar participants at the University of California, Berkeley; the University of Illinois, Urbana-Champaign; the Center on Democracy, Development, and the Rule of Law at Stanford University; and the Kellogg Institute for International Studies at the University of Notre Dame. Thanks to the Kellogg Institute for research support, and to Eduardo Leoni, Lúcio Rennó, and Cesar Zucco for data assistance. Replication data are available at http://www.taylorboas.com or http://www.fdhidalgo.org.

American Journal of Political Science, Vol. 00, No. 0, xxx 2011, Pp. 1-17

(C2011, Midwest Political Science Association

DOI: $10.1111 / j .1540-5907.2011 .00532 . x$ 
Estimates range from 14 to 27 percentage points, more than double the baseline approval rate in three out of four specifications. We attribute this effect to political bargaining between city council members and federal deputies in a position to influence the fate of a radio license application.

Next, we demonstrate that control of community radio can serve as a mechanism of incumbency advantage by influencing electoral outcomes. Using matching, we compare city council candidates who acquired community radio licenses before the 2004 or 2008 election campaigns to similar candidates who did not. We show that the existence of a licensed radio station with ties to a candidate raises his or her vote share by $17 \%$ and probability of winning by $28 \%$. This substantial impact is partially explained by Brazil's system of open-list proportional representation with single city-wide districts. Under these rules, candidates are routinely elected with small vote shares and a geographically concentrated support base, so altering the media environment for even a single neighborhood can improve one's prospects.

The results of this article demonstrate that control of communication media is an important mechanism for perpetuating local political power in Brazil. These findings have implications for other media and higher-level offices, as well as for the study of incumbency advantage, media control, and the spoils of office more generally.

\section{The Spoils of Office, Incumbency Advantage, and Media Control}

Winning elections is attractive to politicians in part because of the spoils of office: the illicit or ethically questionable benefits they stand to gain by leveraging their control over public policy. Research into this question in both new and established democracies has focused almost exclusively on the financial returns to officeholding (Acemoglu et al. 2008; Eggers and Hainmueller 2009; Lenz and Lim 2009; Querubin and Snyder 2009). Yet politicians and parties who abuse public trust through rent seeking may find themselves punished rather than rewarded at the polls (Titiunik 2009). This is particularly true if they spend corrupt earnings on highly visible personal consumption rather than clientelistic distributions to their constituents. For those who seek enrichment, holding office may be a limited-time opportunity to mine the public purse before being run out by angry voters, rather than a way to perpetuate their political careers.

In many new and developing democracies, a distinct spoil of office-media control-provides politicians the opportunity to enhance rather than undermine their public support. If they can leverage their political power to gain outright ownership of, or substantial influence over, local broadcast media, incumbent politicians should be able to shape their constituents' information environment in ways that favor their reelection. Thus, media control may simultaneously constitute a spoil of office and a mechanism of incumbency advantage. Even where incumbents are generally disadvantaged in future elections because of a widespread tendency toward rent seeking, those who find ways to dominate the airwaves may be able to perpetuate their power over time.

Despite the strong expectation that political control of the media should favor incumbents' reelection, prior research on incumbency advantage has paid little attention to this or other spoils of office. A few studies of the U.S. Congress have focused on the electoral payoff of members' disproportionate access to the media (Ansolabehere, Snowberg, and Snyder 2006; Prior 2006). Yet the specific benefits examined, such as incumbents' inherent newsworthiness or ability to use a subsidized congressional television studio in the 1950s and 1960s, are best described not as spoils of office but as perquisites: legitimate advantages that automatically accompany one's elected position. In this regard, media access is similar to other mechanisms of incumbency advantage that have featured more prominently in the literature, such as legislative franking privileges and opportunities for constituent service (Ansolabehere, Snyder, and Stewart 2000; Cox and Katz 1996; Erikson 1971; Fiorina 1977; Krehbiel and Wright 1983; Levitt and Wolfram 1997; Mayhew 1974). Yet in countries with a weak rule of law, spoils of office are likely to outweigh perquisites in terms of their implications for reelection. On average, a politician who can dictate the coverage of local media should triumph over one who is merely newsworthy.

\section{Brazilian Community Radio: A Political Bargaining Chip}

The control of broadcast media is an important means by which Brazilian political bosses consolidate power and perpetuate their careers over time. Since Brazil's transition from authoritarian rule in 1985, using political criteria to award broadcasting licenses has been part and parcel of the democratic game. In the late 1980s, commercial radio and television concessions were often given directly to politicians as payment for votes on key legislation, such as amendments to the 1988 constitution (Motter 1994). Following a 1995 requirement that such 
licenses be awarded through a competitive bidding process, the object of executive philanthropy simply shifted to noncommercial, "educational" media, which were exempt (Lima and Lopes 2007, 10-16).

Beginning in 1998, the federal government added the category of community radio to its regulatory responsibilities, creating new opportunities for deal making with local political bosses. Brazil's community radio stations are low-power stations, with a maximum broadcast range of one kilometer, that are formally operated by local civic groups such as neighborhood associations. As of June 2009 , there were 2,328 such licensed radio stations in 2,168 of Brazil's 5,564 municipalities. While nearly all of Brazil is covered by signals from commercial radio and television, they are usually broadcast from regional population centers. In the typical small town, therefore, community radio may be the only locally based mass medium. Of all municipalities with a licensed community radio station, $78 \%$ have no other local FM broadcasters. Towns with community radio stations are thus quite representative of Brazilian municipalities in general, which are mostly small and rural. Municipalities served by community radio have a median population of 14,145 , versus 10,449 for Brazil as a whole and 23,936 for those with locally based conventional FM stations. ${ }^{1}$

Survey data rarely cover the small towns where community radio should be most important, so ascertaining listenership is difficult. We are aware of only one survey inquiring about community radio in Brazil, in a relatively large city-Nova Friburgo, RJ, whose population of 175,000 places it in the 98th percentile of Brazilian municipalities. ${ }^{2}$ Nonetheless, these data shed some light on community radio's potential political significance. Asked about their three most important media sources, 3\% of respondents mentioned the local community radio station. Given that its signal covers only $13 \%$ of the town's urban and residential area, this degree of listenership is comparable to that of the most popular commercial radio station, which reaches the entire urban area and was mentioned by $32 \%$ of respondents. In truly small towns, where community radio reaches most residents and there are few if any alternative media, its influence could be substantial.

The bureaucratic process by which community radio licenses are issued allows for substantial political manip-

\footnotetext{
${ }^{1}$ The list of conventional FM radio stations (excluding community radio) was obtained from http://sistemas.anatel.gov.br/srd. Population figures are for the year 2000, from the Brazilian Institute of Geographic and Statistics (IBGE).

${ }^{2}$ The survey was conducted by IBOPE in April 2004. Data were obtained from the Centro de Estudos de Opinião Pública (CESOP), Universidade Estadual de Campinas (survey no. 02092).
}

ulation. As with other noncommercial broadcast media, there is no spectrum auction or competitive bidding process for awarding licenses, allowing for a high level of discretion. The first and most crucial step in the application process involves an extensive review by the Ministry of Communications; only about a quarter of applications make it past this stage. Those that clear the ministerial hurdle are forwarded to Congress, which issues formal broadcasting licenses. Legislative approval is largely a rubber-stamp process, but federal deputies can influence an application's fate in the Ministry of Communications by inquiring into its status, requesting that it be processed more quickly, or otherwise helping it along. Having a legislator "sponsor" one's application in this fashion can be crucial to its chances of getting approved, a fact routinely acknowledged by successful applicants (Ferreira 2006; Mick and Vieira 2003). ${ }^{3}$

Community radio stations are supposed to serve the public rather than fall under the sway of local politicians, and they are required by law to avoid political proselytizing and present multiple viewpoints in their news coverage. However, the opposite often occurs. Examining community radio applications approved by the Ministry of Communications from 1999 to 2005, Lima and Lopes (2007, 39-41) found that more than half had a politician, politician's family member, or campaign donor among the station's board of directors. Several studies have found that community radio is used to support specific politicians during local campaigns, with stations even identifying themselves on the air as "belonging" to a particular candidate (Ferreira 2006; Nunes 2004).

Brazilian politicians at multiple levels have an interest in ensuring that community radio stations are politically controlled. At the municipal level, incumbent or aspiring mayors and city council members stand to benefit from favorable coverage in what may be the sole medium reporting on local politics. In recent interviews, one politician claimed that "community radio is important, principally when it's the only radio station in the city," while a former Minister of Communication described it as "the best thing" for mayors and city council members (Scinocca and Lopes 2010).

Controlling a community radio station should be especially beneficial for city council candidates. In Brazil's open-list proportional representation system, which pits politicians from the same party or coalition against one another, an ability to campaign individually is crucial.

\footnotetext{
${ }^{3}$ During the first two years of the Lula government, $35 \%$ of sponsored applications were approved by the Ministry of Communications, but only $8 \%$ of unsponsored applications cleared the bar (Lima and Lopes 2007, 26-27).
} 
Yet television advertising offers these candidates little opportunity to do so. Broadcast television stations allocate free airtime for campaigning, but for legislative (including city council) elections, parties decide how to divide their block of time among multiple candidates. ${ }^{4}$ Some get shut out entirely; many others receive only a few seconds per week (Kuschnir, Piquet Carneiro, and Schmitt 1998). Regular coverage on a community radio station during the campaign can thus provide a significant boost in visibility. Moreover, city council members are elected in single municipality-wide districts and can gain office with a small and very concentrated support base (the median vote total among winners in 2000, 2004, and 2008 was 290). Thus, getting favorable media coverage out to voters in a small geographical area can make a big difference in electoral prospects.

Federal legislators also have a career interest in facilitating local politicians' control of community radio stations. Brazilian deputies compete for office in single statewide districts, so gaining votes in municipalities distributed throughout the state is a viable strategy for winning future elections (Ames 2001). Candidates in these elections also need good relations with local politicians to be able to campaign around the state without violent disruptions of their rallies and events (Ames 1994). By helping a local politician acquire a community radio license, a federal deputy gains an ally who might pledge the support of his voters in future elections and facilitate the deputy's efforts to campaign in that municipality. Sponsors can also expect favorable coverage on stations that they help get approved. As a former Communication Minister explains, "the legislator gets involved here [in Brasília] to help out the guy [mayor or city council member] who supports him there in the municipality. Then that radio station ends up speaking well of him for the rest of his life" (Scinocca and Lopes 2010, A4).

\section{Hypotheses: The Effects of Incumbency and Media Control}

We hypothesize that incumbent local politicians should be more likely than challengers to gain approval for proposed radio stations. All else equal, incumbents are more logical targets for federal support of radio license applications because they can offer more attractive payment in return. Incumbents control resources that can be used to build clientelistic networks and more effectively deliver votes to their political sponsors. Incumbent local politi-

${ }^{4}$ Paid political advertising on television is prohibited. cians, through their influence over police, municipal infrastructure, and so on, are also in a stronger position to affect whether federal deputies can effectively stage local campaign events. Finally, incumbency should affect the value of favorable coverage by the community radio station in question. Since the local "owner" of a politically controlled radio station is often publicly identified in its programming or is otherwise obvious from the slant of its reporting, favorable coverage of federal politicians will constitute de facto public endorsements. Ceteris paribus, it is better that such endorsements come from a local ally who was popular enough to win an election than one who failed.

We also hypothesize that local politicians can expect a greater share of the vote and higher probability of winning if they control a radio station during the campaign. On average, stations tied to candidates in an upcoming election are likely to be biased in their favor, as has been found in several case studies of community radio broadcasting during campaign periods (Ferreira 2006; Nunes 2004). And in Brazilian municipalities, biased campaign coverage in the mass media should affect individual voting behavior. Prior studies of Brazil and other new democracies have argued that media effects are particularly likely when major sources of political information present onesided electoral coverage (Boas 2005; Lawson and McCann 2005). As discussed above, community radio stations may be the only mass medium covering local political races in small towns. In such places, we would expect biased coverage to have a strong effect on voters who are exposed to it.

Media coverage is also likely to have a greater effect on voting behavior when partisan cues provide a weak basis for choosing among candidates (Boas 2005; Lawson and McCann 2005)—a prominent feature of Brazilian municipal elections. Brazil has a large number of political parties, and politicians routinely switch their party affiliations for opportunistic reasons (Desposato 2006). Across all municipalities, the average effective number of parties in city council elections was 6.1 in 2004 and 6.4 in 2008-strikingly high, given that the average number of seats to be filled was only 9.3. Among city council members who ran in both the 2000 and 2004 elections, 53\% did so on different party labels; from 2004 to 2008, the figure rose to $59 \%$. For voters in these elections, a candidate's party affiliation carries little meaningful information, so information gleaned through the media, including community radio, should weigh more heavily in their decisions.

Finally, the nature of campaigns for city council and the informational demands on voters in these elections lead to an expectation of media effects when a candidate 
controls a community radio station. Given the strategic complexity of competing under open-list proportional representation rules and the large number of candidates for city council (a median of 45 per municipality from 2000 to 2008), campaigns focus largely on individual self-promotion without reference to either opponents or copartisans (Desposato 2004). Candidates with independent resources-which would include influence over a community radio station - tend to concentrate their campaigns in geographically defined strongholds rather than seeking votes city-wide (Kuschnir, Piquet Carneiro, and Schmitt 1998, 72-73). Yet even those who enjoy strong support in their bailiwicks still need to educate voters on how to cast a ballot for them. Brazilians vote electronically by entering a candidate's number, and the ballot does not include a reference sheet of corresponding names. To vote for a city council member, they must correctly enter five digits that typically differ for the same politician across elections. Politicians who control a community radio station can saturate the airwaves with this crucial number. Thus, exposure to biased coverage should not only predispose citizens toward voting for the candidate in question, but also teach them how to do so.

Other mechanisms might also contribute to the effect of community radio control on a candidate's vote share and probability of victory. For example, a city council candidate with a radio station might trade favorable coverage of the mayor for the mayor's endorsement, influencing voters in a roundabout fashion. Given the likelihood of direct media effects as well as indirect mechanisms, we should have a particularly strong expectation that candidates who control community radio stations will benefit at the polls.

\section{Data}

To assess these questions about the causes and effects of community radio control in Brazil, we constructed a unique dataset based on publicly available information from the Ministry of Communications, Chamber of Deputies, Superior Electoral Tribunal (TSE), and Brazilian Institute of Geography and Statistics (IBGE). ${ }^{5}$ We began with the TSE's results from the city council elections of 2000, 2004, and 2008; demographic information on candidates such as their year of birth, education level, and occupation; candidates' personal identification numbers

\footnotetext{
${ }^{5}$ These government databases have a strong reputation for completeness and accuracy, especially in recent years, and are the standard source for quantitative research on Brazilian elections and related topics.
}

(CPFs), which we used to track them across elections; and for 2008, candidates' declared assets. ${ }^{6}$ To augment our candidate-level database, we merged in municipallevel demographic and political data from IBGE, such as Gini coefficients, Human Development Index, and vote share for major parties in prior elections.

From the Ministry of Communications' web site, we downloaded a list of 13,959 entities that had responded to public calls for community radio license applications ( avisos de habilitação) as of June 16, 2009. ${ }^{7}$ We then created a three-category outcome variable for each application: rejected by the Ministry of Communications, approved, or still pending. We also obtained the application date for each proposed station, and, for those applications that had cleared subsequent hurdles, the dates of approval by the Ministry, being forwarded to Congress, and receiving a broadcasting license. Unfortunately, decision dates for applications that were rejected by the Ministry of Communications are not publicly available. For the analysis of incumbency effects on license approval, therefore, the only way to ensure that an outcome is posttreatment is to restrict the analysis to entities that applied after the relevant election.

To identify city council candidates who had ties to proposed community radio stations, we matched the names of the candidates from each municipality with the names of the legal representatives for that municipality's radio license requests. The name of a proposed station's legal representative is attached to a license application throughout every stage of the process; this individual is typically the protagonist behind the station's creation. Politicians can gain sway over a station in other ways as well, many of them informal, but when a candidate for local office becomes a proposed station's legal representative, we can be certain of a political tie. Since we are distinguishing among politicians with a radio station who won or lost the election, rather than those who do or do not control a station, conservatively estimating political ties should induce no bias.

For examining the effect of incumbency on the fate of community radio applications, our final database contains all 583,897 city council candidates in the 2000 and 2004 elections. Respectively, 1,244 and 1,135 candidates in these two elections were legal representatives of proposed radio stations, though they could have applied at any time since the first call for applications in November

\footnotetext{
${ }^{6}$ These data were downloaded from the TSE's web site, http://www.tse.gov.br. The files exclude candidates who were legally registered but received zero votes. For 2008, some data were also obtained from http://eleicoes.uol.com.br/2008/candidatos.
}

${ }^{7}$ These data are available at http://www.mc.gov.br/radiocomunitaria. 
1998. Most of our analysis of incumbency effects focuses on the subset of candidates $(n=716)$ who applied for a community radio license after competing in an election, after Lula took office (January 1, 2003), and prior to the 2008 election. ${ }^{8}$

To examine the effect of community radio control on politicians' subsequent electoral prospects, our final database contains all city council candidates in the 2004 and 2008 elections who were issued radio licenses prior to the official start of the campaign ( 45 days before the election), as well as those whom we consider potentially valid counterfactuals for this group of "treated" candidates. This database consists of 1,455 city council candidates. Descriptive statistics for both samples can be found in an online appendix.

\section{The Effect of Incumbency on Media Control}

In analyzing the effect of incumbency, the regression discontinuity design exploits the fact that political actors cannot precisely control electoral outcomes. While candidates can certainly influence the result of an election through canvassing, advertising expenditures, vote buying, and other campaign activities, the number of votes they receive on election day is subject to inherent uncertainty. For example, in a hypothetical race where winning and losing candidates are separated by a margin of 10 votes, the outcome could easily have been caused by numerous "random" factors other than the winner's campaign prowess. If rain or a traffic jam in the loser's bailiwick suppressed turnout even marginally, the winner will have gained office for reasons unrelated to the characteristics of the two candidates. In other words, for candidates who win or lose by a narrow margin, political office can sometimes be treated "as if" it were assigned at random.

To date, most applications of the regression discontinuity design to elections have involved single-member districts. In this article, we adapt the RD design to the open-list proportional representation rules used in Brazil's legislative elections. Brazilian voters typically vote for candidates, but seats are first distributed to parties or coalitions of parties. The candidates in winning parties or coalitions are then ranked by number of personal votes, and the seats won are awarded in that order. In this article,

${ }^{8}$ When a politician applied for a community radio station after competing in both the 2000 and 2004 elections, we use only the results of the latter. we are interested in the effect of personal incumbency on the fate of radio license applications. Hence, we focus on the rules determining whether individual candidates win or lose, that is, the intracoalition stage of seat allocation.

Formally, a coalition $j$ wins $s_{j}$ seats. Each candidate is indexed by $i$, which also denotes intracoalition rank, as determined by his $v_{i j}$ votes. ${ }^{9}$ The candidates with $i \leq$ $s_{j}$ win office and become incumbents, while those with $i>s_{j}$ lose. The "last winner" is the candidate with $i=$ $s_{j}$, whose vote total can be written as $v_{i=s, j}$. Similarly, the "first loser" is the candidate with $i=s_{j}+1$, whose vote total is denoted as $v_{i=s+1, j}$. Candidate $i$ 's margin of victory or defeat, $M_{i j}$, can be defined as follows:

$$
M_{i j}=\left\{\begin{array}{lll}
v_{i j}-v_{i=s+1, j} & \text { if } \quad i \leq s_{j} \\
v_{i=s, j}-v_{i j} & \text { if } \quad i>s_{j}
\end{array}\right.
$$

In words, a winning (losing) candidate's vote margin will be the difference between his vote total and that of the first loser (last winner). Naturally, vote margin determines incumbency status: $I_{i j}=1$ if $M_{i j}>0$, and $I_{i j}=0$ if $M_{i j}<0$.

We wish to estimate the quantity $\tau=\mathbb{E}\left[Y_{i j}(1)-\right.$ $\left.Y_{i j}(0)\right]$, where $Y_{i j}(1)$ and $Y_{i j}(0)$ denote the outcome of interest (radio station approval, for example) for candidate $i$ in coalition $j$ when he is an incumbent and a loser, respectively. This estimand is unidentified without further assumptions since we only observe $Y_{i j}(1) \mid I_{i j}=1$ and $Y_{i j}(0) \mid I_{i j}=0$, but not $Y_{i j}(1) \mid I_{i j}=0$ and $Y_{i j}(0) \mid I_{i j}=1$.

As is well established in the RD literature (e.g., Lee 2008), the decision rule at the heart of electoral politics allows one to estimate causal incumbency effects because one can couple the relatively innocuous assumption that the distribution of potential outcomes is a smooth function of the vote margin with the fact that incumbency is allocated discontinuously when the vote margin is zero. Under this smoothness assumption about $Y_{i j}(1)$ and $Y_{i j}(0)$, one can identify a local causal effect at $M_{i j}=$ 0 since on either side of the threshold (with a minimum amount of extrapolation), the outcomes of incumbents are valid counterfactuals for the outcomes of losers (Imbens and Lemieux 2007). Thus, in this article we focus on the following quantity:

$$
\tau_{R D}=\mathbb{E}\left[Y_{i j}(1) \mid M_{i j}=0\right]-\mathbb{E}\left[Y_{i j}(0) \mid M_{i j}=0\right]
$$

This estimand is a "local" average treatment effect (LATE), since it only represents the effect among candidates who barely win or barely lose.

\footnotetext{
${ }^{9}$ Ties are broken by giving the older candidate the higher rank. Since this rule introduces imbalance in age among winners and losers, we drop candidates with a zero vote margin.
} 
Under the assumptions outlined above, in a window around $M_{i j}=0$, whether or not a candidate ends up as an incumbent should be as good as random. Fortunately for our purposes, Brazil's high district magnitude tends to fragment the electorate, resulting in many candidates winning or losing by small vote margins. Among all winning city council candidates in 2000 and 2004, for example, the median margin of victory was only 66 votes, or $1 \%$ of the municipal electorate.

Furthermore, as a result of coalition-level vote pooling, there is a relatively weak relationship between votes won and incumbency status (Desposato 2009), which strengthens our "as if" random assumption. Seats are distributed to a coalition based on the number of total votes received by all its candidates, but a small number of popular candidates often contribute the majority of these coalition votes. If vote totals are highly concentrated in this fashion, many of the electorally weaker candidates will win office with relatively few personal votes, as they are swept into power on the electoral strength of their copartisans. As a result, victorious candidates may have received fewer personal votes than losers from less dominant coalitions.

In this article, we use raw vote margin as our forcing variable rather than vote margin as a share of total valid votes. Brazilian municipalities vary greatly in size, from several hundred voters to several million, so close elections defined by vote share occur disproportionately in large cities. Yet as discussed above, most community radio stations are located in small- and medium-sized municipalities, so using standardized vote margin as a forcing variable would make our sample less representative in terms of population, a crucial covariate. ${ }^{10}$ The theoretical expectation of an incumbency effect is strongest in small towns: acquiring a community radio station should be more attractive where its signal reaches a larger share of residents and it faces fewer competing media, so incumbents in small towns should bargain harder to get one. By using raw vote margin as our forcing variable, we ensure that our samples of bare winners and losers will contain plenty of small-town candidates, who are of greatest theoretical interest. ${ }^{11}$

\footnotetext{
${ }^{10}$ When using vote margin as a share of valid votes, the median municipal population in our local linear regression sample was 22,780 , versus 6,936 when using raw vote margin and 10,449 for Brazil as a whole.

${ }^{11}$ As a robustness check, we calculated balance statistics and effect estimates for several alternative forcing variables (reported in the online appendix). For vote margin as a share of all valid votes in the municipality, we obtained notably worse balance (two to four significant covariates per specification and several failed placebo tests), arguing against the "as if" random assumption. Effect esti-
}

To examine the validity of our "as if" random assumption, we tested the continuity of the density of the forcing variable using the test proposed by McCrary (2008). If, contrary to our assumption, candidates were able to manipulate their raw vote margins with a high degree of precision, there should be a notable break in the density at the zero point, as candidates who realized they were going to lose by a handful of votes expended extra energy (or manipulated the vote count) to push themselves into the winning column. Our design passed the test: we were unable to reject the null hypothesis of no difference in density at the cutpoint (Wald statistic-0.16, SE 0.22).

Our first specification estimates the conditional expectation function on each side of the discontinuity using the following local linear regression:

$$
\begin{aligned}
\min & \sum_{j=1}^{J} \sum_{i=1}^{N_{j}} 1\left\{-h \leq M_{i j} \leq h\right\} . \\
& \left(Y_{i j}-\alpha-\beta \cdot M_{i j}-\tau_{R D} \cdot I_{i j}-\gamma \cdot M_{i j} \cdot I_{i j}\right)^{2}
\end{aligned}
$$

Our parameter of interest is $\tau_{R D}$. The variable $h$ is the bandwidth, which specifies how much data in a window around $M_{i j}=0$ are retained for estimating $\tau_{R D}$. We use the cross-validation procedure recommended by Imbens and Lemieux (2007) to determine $h .{ }^{12}$ Our optimal bandwidth is 165 votes, which retains about $54 \%$ of radio license applicants, for an $n$ of 384 candidates.

In addition to the local linear regression, we also estimate $\tau_{R D}$ by calculating the simple difference in means using data from increasingly smaller windows ("discontinuity samples") around the zero vote margin threshold. ${ }^{13}$

mates were similar in size to those for raw vote margin, though less consistently significant (and also less believable, given the imbalance). We do obtain larger and more consistently significant results with this alternative forcing variable when looking only at small towns, supporting our conjecture about heterogeneous treatment effects by municipality size. In addition to standardized vote margin, we also examined results using an "inflated vote margin" that seeks to "punish" candidates in small municipalities whose margin of victory or loss is large relative to their total votes (e.g., losing by 40 votes but only receiving 80 ). To calculate this quantity, we multiplied raw vote margin $M_{i j}$ by $v_{i j} /\left(v_{i j}-M_{i j}\right)$ for winning candidates and $\left(v_{i j}-M_{i j}\right) / v_{i j}$ for losing candidates. Balance and results were similar to those reported below.

${ }^{12}$ The cross-validation algorithm determines an optimal bandwidth by minimizing the prediction error of the local linear regression when used to predict the outcome variable for each observation using a sequence of bandwidths. We tested 100 different possible values of $h$ on a trimmed dataset, dropping observations with vote margins (absolute value) larger than the 60th percentile.

${ }^{13}$ We also tried a third- and fourth-order polynomial fit to estimate $\tau_{R D}$, but covariate balance was worse than in our other specifications. Treatment effect estimates using the polynomial specification were comparable to the estimates reported below, albeit somewhat smaller. 
We use bandwidths of $40(n=141), 20(n=62)$, and 10 $(n=33)$. The narrower the window around the discontinuity, the smaller the dataset used to estimate our effect, which can increase the uncertainty of our estimates. The "as if random" assumption, however, becomes more plausible with smaller bandwidths. With a margin of only 10 votes, whether or not a candidate takes office is more likely the result of chance factors, as opposed to background differences between winners and losers.

To gain greater assurance that winners and losers in close elections do not differ from one another on important background characteristics that could affect the fate of their radio license applications, we can conduct a placebo test, which examines whether our research design can recover a known effect. Using our full dataset of 583,897 city council candidates from the 2000 and 2004 elections, we examine the effect of incumbency on application approval prior to the election. Because this effect is zero by construction, any statistically significant result would have to be attributed to background differences between winners and losers, which could bias our estimates of the effect of incumbency on future application approval. Using each of the four specifications discussed above, our design passes the placebo test, as shown in the top panel of Table 1 . None of the estimates is statistically significant at the $5 \%$ level, and the point estimates are minuscule.

As discussed above, the lack of publicly available decision dates for rejected applications means that the only way to ensure that the outcome of interest occurred after the treatment is to condition on applying for a radio license after the election that determined incumbency status. Doing so risks bias, however, because winning or losing the election might lead politicians to apply for radio licenses at different rates. To condition on a posttreatment variable without inducing bias, we need to show that it is unaffected by the treatment (Rosenbaum 1984)-i.e., that incumbency is irrelevant to politicians' decisions to apply for a community radio license.

As shown in the top panel of Table 1, we find no evidence that incumbency affects the decision to apply for a community radio license. Our point estimates are all extremely small, and despite the large sample sizes, none is statistically significant. Furthermore, no effect is detected even when examining candidates who won or lost by a single vote $(n=2,036)$. Given these results, conditioning on having applied for a license will not induce posttreatment bias in our estimates.

An important implication of our identifying assumptions is that winners and losers in close elections will be similar on background characteristics. To check covariate balance, we looked at attributes of both candidates and license applications, as well as characteristics of the corresponding municipality. Because of our decision to condition on applying for a radio license when estimating treatment effects, we limit balance testing to radio applicants.

To check balance, we estimated the difference across elected and nonelected candidates using the local linear regression specification, as well as calculating the difference in means in the full sample and the three discontinuity samples. The bottom panel of Table 1 shows the estimates for 18 covariates, with heteroskedasticityconsistent standard errors in parentheses. In the full sample, there are substantial differences on some key covariates, such as the size of the municipal electorate and the number of votes received by a candidate's coalition. Restricting the sample, balance improves on most covariates, though it worsens or remains the same on a few variables, depending on the specification. Overall, covariate balance is not perfect, but it is approximately what one would expect if incumbency status had been randomly assigned. Moreover, no covariate is unbalanced across more than one specification. Thus, if effect estimates tell the same story in the local linear regression and the three discontinuous samples, we can be fairly confident that the result is not due to confounding.

\section{Results}

The results of our analysis are consistent across all specifications: incumbency substantially increases the probability of a community radio application's approval and reduces the probability of its rejection. Figure 1 graphically displays the effect of incumbency on approval (versus being rejected or still pending at the time of data collection) and rejection (versus being approved or still pending). The dots represent mean values of an indicator variable for application approval or rejection in "bins" of the vote margin, with each bin encompassing an equal number of candidates. To the left of the dotted vertical line, candidates lose, and to the right, they win. The solid lines in the plot are a locally weighted polynomial fit on each side of the cutpoint; the dashed lines give a bootstrapped 95\% confidence interval. The gap between the lines at $M_{i j}=$ 0 suggests that incumbency has a large positive effect on the probability of an application's approval by the Ministry of Communications and a large negative effect on the probability of its rejection.

Somewhat counterintuitively, Figure 1 also shows that applications are less likely to be approved and more likely to be rejected as one moves toward greater winning vote margins. We interpret this pattern as an effect of 
TABle 1 Balance Statistics for Four Different Specifications

\begin{tabular}{|c|c|c|c|c|c|}
\hline Variable & Full Sample & $\begin{array}{l}\text { Local Linear } \\
\left(\left|M_{i j}\right| \leq 165\right)\end{array}$ & $\begin{array}{l}\text { Discont. Sample } \\
\quad\left(\left|M_{i j}\right| \leq \mathbf{4 0}\right)\end{array}$ & $\begin{array}{l}\text { Discont. Sample } \\
\qquad\left(\left|M_{i j}\right| \leq \mathbf{2 0}\right)\end{array}$ & $\begin{array}{l}\text { Discont. Sample } \\
\qquad\left(\left|M_{i j}\right| \leq 10\right)\end{array}$ \\
\hline Apply for a License & $\begin{array}{c}1.3 \times 10^{-4} \\
\left(1.2 \times 10^{-4}\right)\end{array}$ & $\begin{array}{c}5.7 \times 10^{-5} \\
\left(2.6 \times 10^{-4}\right)\end{array}$ & $\begin{array}{l}-1.4 \times 10^{-4} \\
\left(2.5 \times 10^{-4}\right)\end{array}$ & $\begin{array}{l}-2.7 \times 10^{-4} \\
\left(3.4 \times 10^{-4}\right)\end{array}$ & $\begin{array}{l}-2.1 \times 10^{-4} \\
\left(5.0 \times 10^{-4}\right)\end{array}$ \\
\hline Prior Approval & $\begin{array}{l}3.7 \times 10^{-4 *} \\
\left(8.6 \times 10^{-5}\right)\end{array}$ & $\begin{array}{c}-2.8 \times 10^{-4 \dagger} \\
\left(1.6 \times 10^{-4}\right)\end{array}$ & $\begin{array}{c}9.1 \times 10^{-5} \\
\left(1.3 \times 10^{-4}\right)\end{array}$ & $\begin{array}{c}8.5 \times 10^{-5} \\
\left(2.0 \times 10^{-4}\right)\end{array}$ & $\begin{array}{l}-4.4 \times 10^{-5} \\
\left(2.9 \times 10^{-4}\right)\end{array}$ \\
\hline$n$ (all candidates) & 583,897 & 299,477 & 92,720 & 46,733 & 23,216 \\
\hline Year of Birth & $\begin{array}{c}0.61 \\
(0.84)\end{array}$ & $\begin{array}{c}-1.53 \\
(1.9)\end{array}$ & $\begin{array}{c}0.67 \\
(1.76)\end{array}$ & $\begin{array}{c}-1.87 \\
(2.48)\end{array}$ & $\begin{array}{r}2.15 \\
(3.3)\end{array}$ \\
\hline Log Coalition Votes & $\begin{array}{c}-0.63^{*} \\
(0.1)\end{array}$ & $\begin{array}{l}0.05 \\
(0.13)\end{array}$ & $\begin{array}{c}-0.07 \\
(0.13)\end{array}$ & $\begin{array}{c}-0.01 \\
(0.17)\end{array}$ & $\begin{array}{c}0.08 \\
(0.22)\end{array}$ \\
\hline Primary Education & $\begin{array}{c}0.04 \\
(0.04)\end{array}$ & $\begin{array}{c}-0.06 \\
(0.08)\end{array}$ & $\begin{array}{c}0.02 \\
(0.08)\end{array}$ & $\begin{array}{c}-0.19 \\
(0.12)\end{array}$ & $\begin{array}{r}-0.39^{*} \\
(0.16)\end{array}$ \\
\hline São Paulo & $\begin{array}{c}-0.03 \\
(0.03)\end{array}$ & $\begin{array}{c}-0.02 \\
(0.05)\end{array}$ & $\begin{array}{c}0.01 \\
(0.05)\end{array}$ & $\begin{array}{c}0.02 \\
(0.09)\end{array}$ & $\begin{array}{c}0.09 \\
(0.11)\end{array}$ \\
\hline Minas Gerais & $\begin{array}{r}-0.06^{*} \\
(0.03)\end{array}$ & $\begin{array}{r}-0.14^{*} \\
(0.06)\end{array}$ & $\begin{array}{c}-0.09 \\
(0.05)\end{array}$ & $\begin{array}{l}-0.1 \\
(0.09)\end{array}$ & $\begin{array}{c}-0.07 \\
(0.14)\end{array}$ \\
\hline Occupation: Agriculture & $\begin{array}{c}0.02 \\
(0.03)\end{array}$ & $\begin{array}{c}0.1 \dagger \\
(0.06)\end{array}$ & $\begin{array}{c}0.07 \\
(0.06)\end{array}$ & $\begin{array}{c}0.11 \\
(0.09)\end{array}$ & $\begin{array}{c}0.07 \\
(0.07)\end{array}$ \\
\hline Occupation: Business & $\begin{array}{c}0.05 \\
(0.03)\end{array}$ & $\begin{array}{c}0.03 \\
(0.06)\end{array}$ & $\begin{array}{c}0.02 \\
(0.06)\end{array}$ & $\begin{array}{c}0.03 \\
(0.07)\end{array}$ & $\begin{array}{c}0 \\
(0)\end{array}$ \\
\hline Party: PMDB & $\begin{array}{c}0.05 \\
(0.03)\end{array}$ & $\begin{array}{c}-0.04 \\
(0.08)\end{array}$ & $\begin{array}{l}-0.07 \\
(0.07)\end{array}$ & $\begin{array}{c}-0.07 \\
(0.08)\end{array}$ & $\begin{array}{c}-0.09 \\
(0.12)\end{array}$ \\
\hline Party: PSDB & $\begin{array}{c}0.04 \\
(0.03)\end{array}$ & $\begin{array}{c}0.02 \\
(0.06)\end{array}$ & $\begin{array}{c}0.03 \\
(0.05)\end{array}$ & $\begin{array}{c}0.05 \\
(0.08)\end{array}$ & $\begin{array}{c}0.04 \\
(0.13)\end{array}$ \\
\hline Party: PFL & $\begin{array}{c}0.01 \\
(0.03)\end{array}$ & $\begin{array}{l}0 \\
(0.07)\end{array}$ & $\begin{array}{c}0.02 \\
(0.06)\end{array}$ & $\begin{array}{r}0.01 \\
(0.1)\end{array}$ & $\begin{array}{c}-0.09 \\
(0.12)\end{array}$ \\
\hline Lula Vote Share, 1998 & $\begin{array}{l}0 \\
(0.01)\end{array}$ & $\begin{array}{r}0.04^{*} \\
(0.02)\end{array}$ & $\begin{array}{r}0.03 \dagger \\
(0.02)\end{array}$ & $\begin{array}{c}0.05 \\
(0.03)\end{array}$ & $\begin{array}{c}0.07 \\
(0.04)\end{array}$ \\
\hline Gini (2000) & $\begin{array}{r}-0.01 \dagger \\
(0.01)\end{array}$ & $\begin{array}{l}0 \\
(0.01)\end{array}$ & $\begin{array}{l}0 \\
(0.01)\end{array}$ & $\begin{array}{c}0.01 \\
(0.02)\end{array}$ & $\begin{array}{c}0.01 \\
(0.02)\end{array}$ \\
\hline Latitude & $\begin{array}{r}-1.15 \\
(0.84)\end{array}$ & $\begin{array}{c}-1.81 \\
(1.74)\end{array}$ & $\begin{array}{c}-1.69 \\
(1.62)\end{array}$ & $\begin{array}{l}-1.4 \\
(2.29)\end{array}$ & $\begin{array}{l}-4.1 \\
(3.01)\end{array}$ \\
\hline Longitude & $\begin{array}{c}0.62 \\
(0.57)\end{array}$ & $\begin{array}{l}-0.6 \\
(1.23)\end{array}$ & $\begin{array}{c}0.61 \\
(1.13)\end{array}$ & $\begin{array}{c}0.38 \\
(1.63)\end{array}$ & $\begin{array}{l}1.76 \\
(2.04)\end{array}$ \\
\hline HDI (2000) & $\begin{array}{c}-0.01 \\
(0.01)\end{array}$ & $\begin{array}{c}0.01 \\
(0.02)\end{array}$ & $\begin{array}{c}0.01 \\
(0.01)\end{array}$ & $\begin{array}{l}0 \\
(0.02)\end{array}$ & $\begin{array}{c}0.02 \\
(0.03)\end{array}$ \\
\hline PT Mayor (2000) & $\begin{array}{r}-0.04^{*} \\
(0.02)\end{array}$ & $\begin{array}{c}-0.03 \\
(0.02)\end{array}$ & $\begin{array}{r}-0.05^{*} \\
(0.02)\end{array}$ & $\begin{array}{c}-0.05 \\
(0.04)\end{array}$ & $\begin{array}{c}-0.05 \\
(0.05)\end{array}$ \\
\hline Log Electorate & $\begin{array}{r}-1.02^{*} \\
(0.13)\end{array}$ & $\begin{array}{c}0.04 \\
(0.15)\end{array}$ & $\begin{array}{c}-0.11 \\
(0.14)\end{array}$ & $\begin{array}{r}-0.02 \\
(0.19)\end{array}$ & $\begin{array}{c}0.01 \\
(0.27)\end{array}$ \\
\hline Time Since Application & $\begin{array}{l}132.37^{*} \\
(45.18)\end{array}$ & $\begin{array}{c}125.56 \\
(107.24)\end{array}$ & $\begin{array}{c}113.6 \\
(102.63)\end{array}$ & $\begin{array}{c}61.83 \\
(145.83)\end{array}$ & $\begin{array}{r}-156.09 \\
(187.74)\end{array}$ \\
\hline$n$ (radio applicants) & 713 & 384 & 131 & 62 & 33 \\
\hline
\end{tabular}

Note: Heteroskedasticity-consistent standard errors in parentheses. ${ }^{\dagger} \mathrm{p}<0.1 ;{ }^{*} \mathrm{p}<.05$. 
FIGURE 1 The Effect of Incumbency on Community Radio Application Approval and Rejection

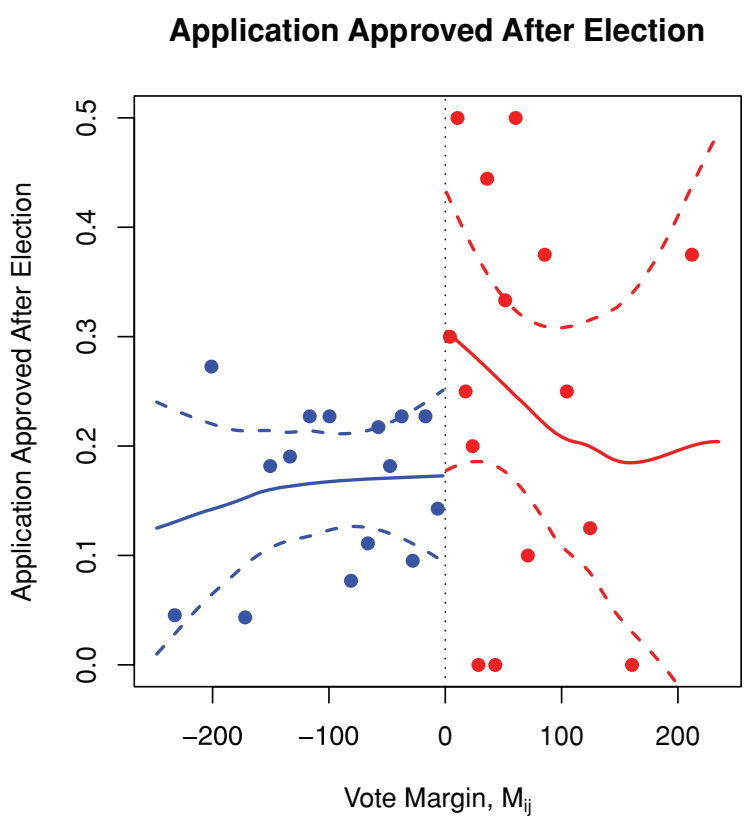

Application Rejected After Election

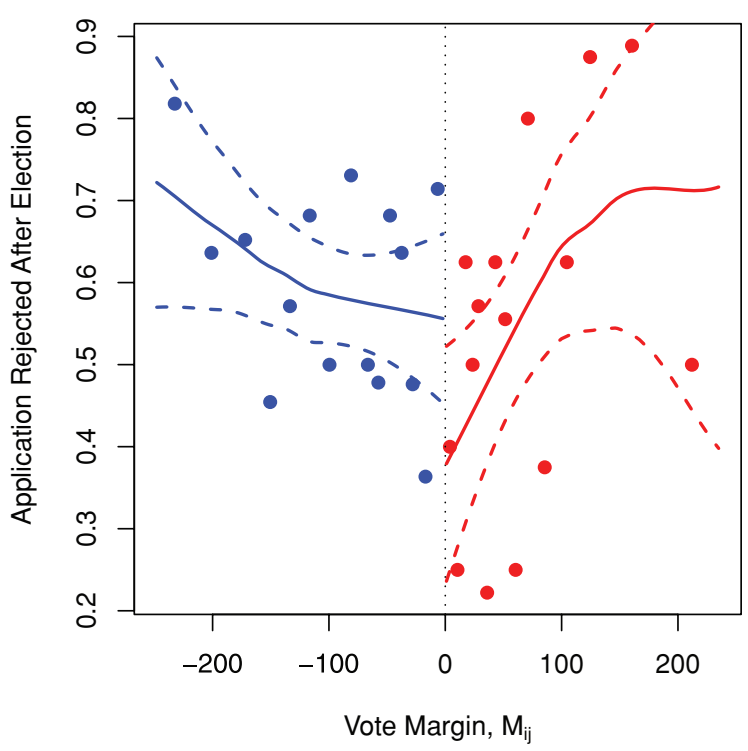

Note: The dots represent mean values in "bins" of the vote margin, with each bin encompassing an equal number of candidates. The solid line is a locally weighted polynomial fit, and the dashed lines give bootstrapped 95\% confidence intervals.

municipality size: candidates winning by large margins tend to be in large cities, where there is greater competition among multiple applicants for a single radio license.
The variance of application approval is also significantly greater among winning candidates than losing candidates $\left(F_{148,568}=1.44, \mathrm{p}=.002\right)$, though the same is not true of application rejection $\left(F_{148,568}=1.10, \mathrm{p}=\right.$ .228). We suspect that regulators always avoid rejecting the applications of incumbents, but may not discriminate as consistently between approval and leaving them pending. This pattern would account for the observed difference in variances, since pending applications receive a zero score on both the "approved" and "rejected" outcomes.

Formal estimates of the effect of incumbency on approval and rejection, using the specifications discussed above, can be found in Table 2. For application approval, all four estimates are large and statistically significant at either the 5\% level (local linear regression and the $\left|M_{i j}\right| \leq$ 20 discontinuity sample) or the $10 \%$ level (the $\left|M_{i j}\right| \leq$ 40 and $\left|M_{i j}\right| \leq 10$ discontinuity samples). The point estimates range from a low of .14 for the $\left|M_{i j}\right| \leq 40$ sample to a high of .27 for the $\left|M_{i j}\right| \leq 10$ sample. For application rejection, estimates range from -.13 for the $\left|M_{i j}\right| \leq 40$ sample to a very large -.40 for the $\left|M_{i j}\right| \leq 10$ sample. The estimates from the local linear model and the smallest discontinuity sample are statistically significant at the 5\% level, while the others are not.

According to our estimates, incumbency is a very potent asset for those politicians seeking radio licenses. For losing candidates at the discontinuity point, the estimated probability of approval is 0.158 for the two smallest discontinuity samples, 0.171 for the largest discontinuity sample, and 0.166 for the local linear regression. Thus, three of the four treatment effect estimates represent a more than doubling of the probability of having one's application approved.

\section{The Effect of Media Control on Electoral Outcomes}

Identifying the causal effect of community radio control on a politician's electoral prospects presents more challenges than identifying the effect of incumbency on an application's chances of approval or rejection. Unlike electoral victories, the awarding of radio licenses is not a deterministic function of some continuous covariate such as vote margin, so we cannot identify a group of radio applicants for whom license acquisition can be considered "as if" random. Rather, federal regulators award community radio licenses according to both technical and political criteria, including an applicant's incumbency status, as we have just shown. Many of these same criteria are 
TABLE 2 The Effect of Incumbency on Community Radio Application Approval and Rejection

\begin{tabular}{llcccc}
\hline DV & $\begin{array}{c}\text { Local Linear } \\
\left(\left|\boldsymbol{M}_{i j}\right| \leq \mathbf{1 6 5}\right)\end{array}$ & $\begin{array}{c}\text { Discont. Sample } \\
\left(\left|\boldsymbol{M}_{i j}\right| \leq \mathbf{4 0}\right)\end{array}$ & $\begin{array}{c}\text { Discont. Sample } \\
\left(\left|\boldsymbol{M}_{i j}\right| \leq \mathbf{2 0}\right)\end{array}$ & $\begin{array}{c}\text { Discont. Sample } \\
\left(\left|\boldsymbol{M}_{i j}\right| \leq \mathbf{1 0}\right)\end{array}$ \\
\hline Approval & $\hat{\tau}_{R D}$ & $0.17^{*}$ & $0.14 \dagger$ & $0.22^{*}$ & $0.27 \dagger$ \\
& $S E$ & 0.08 & 0.07 & 0.11 & 0.15 \\
\multirow{4}{*}{ Rejection } & $n$ & 384 & 131 & 62 & 33 \\
& $\hat{\tau}_{R D}$ & $-0.24^{*}$ & -0.13 & -0.20 & $-0.40^{*}$ \\
& $S E$ & 0.10 & 0.09 & 0.13 & 0.17 \\
& $n$ & 384 & 131 & 62 & 33 \\
\hline
\end{tabular}

Note: Standard errors are heteroskedasticity consistent.

${ }^{\dagger} \mathrm{p}<0.1 ;{ }^{*} \mathrm{p}<.05$.

likely to have independent effects on a candidate's future electoral prospects. To obtain an unbiased estimate of the effect of media control (the treatment) on electoral outcomes, we must condition on these potential confounders.

To isolate the effect of community radio control on electoral outcomes, we employ a matching design. Matching seeks to simulate the context of an experiment by comparing observations that received a treatment to a subset of those that did not receive it (the control group). This subset is chosen such that the distribution of observed pretreatment covariates - those that cannot be considered a consequence of the treatment itself-is similar across groups. In contrast to regression, control observations that had little chance of receiving the treatment are dropped from the analysis and cannot bias the causal estimate. If the matching procedure achieves balance across groups with respect to all covariates that affect both treatment assignment and the outcome, simple mean differences offer an unbiased estimate of the average treatment effect on the treated (ATT). Unlike regression, matching is a nonparametric procedure that does not require any modeling assumption about how these observed covariates are related to the treatment and the outcome of interest.

Like regression, matching does require the assumption of no confounding, or selection on observablesnamely, that no unobserved covariate affects treatment assignment as well as the outcome. Fortunately, our dataset contains a wealth of candidate-, application-, and municipal-level variables on which we can condition, lessening the severity of this assumption. Nevertheless, it is likely that some unobserved confounders remain unaccounted for and that our estimates will contain a degree of bias, as with nearly any matching or regression analysis in the social sciences.

To identify the treatment group and an initial (prematching) control group, our first goal was to ensure that selection into treatment or control was a function of the regulatory process rather than candidates' personal decisions. The treatment group is defined as those candidates whose radio stations had received a broadcasting license before the start of free campaign advertising on radio and television, 45 days before the election, and thus could legally operate during the campaign $(n=311)$. Official campaign advertising is not broadcast on community radio stations, but the campaign advertising period is when candidates are focusing most intensely on campaign communication and voters are most attentive to what they have to say. Moreover, information on candidates' assets (as well as demographic data) is collected several weeks prior to this date, ensuring that we can condition on these covariates without posttreatment bias.

We define the initial control group as candidates who applied for a community radio license in similar municipalities but had not received any positive response before the relevant election-either because their applications were rejected at any time $(n=907)$, received ministerial approval only after the election $(n=94)$, or were still pending as of June $2009(n=143)$. We thus exclude all candidates who never applied for a community radio license or who applied only after the election. Such candidates might not have bothered with an application because they enjoyed other advantages, including preferential access to commercial media, that would affect their electoral performance vis-à-vis the treatment group. We also exclude groups of candidates that may have "partially" received the treatment. These include candidates whose licenses were issued during (rather than before) the 45-day official campaign period, as well as those who received approval from the Ministry of Communications before the election but only acquired their licenses afterwards. Since ministerial approval almost always leads to eventual licensing, some entities begin illegally broadcasting after receiving an approval notice, but others do not (Mick and Vieira 2003). Finally, we exclude candidates 
from Brazilian cities with more than 2 million residentsSão Paulo, Rio de Janeiro, Salvador, Fortaleza, Brasília, and Belo Horizonte-since all of the treated candidates were from smaller municipalities. ${ }^{14}$

Even after restricting the control group to those candidates who applied but received no positive response before an election, the difference between treated and control politicians will likely be confounded by factors that are correlated with both a successful application and electoral outcomes. As shown in the prior section, approval or denial of a license is-in part-determined by political factors like incumbency. Indeed, we find considerable imbalance in an important set of pretreatment variables, as documented in Table 3. To reduce or eliminate this kind of confounding, we match on a rich set of covariates, including socioeconomic characteristics of the candidates, features of the municipalities in which they run for office, and past electoral performance for those candidates who ran in previous elections.

The degree to which our matching procedure successfully eliminates confounding depends on how well conditioning on observed covariates accounts for aspects of the treatment assignment mechanism that could also influence election outcomes. The factors that appear most influential in treatment assignment, by virtue of being most highly unbalanced before matching, are characteristics of the application itself. A first feature is how long before the election the application was filed, since candidates only fall into the treatment group if their applications have successfully cleared numerous bureaucratic hurdles before the start of the campaign. A second relevant feature is how much competition the application faced, since only a limited number of community radio stations can be licensed in each municipality. We match on the number of entities from the municipality that responded to the relevant call for applications, though we do not match on time since application; the latter was so influential in treatment assignment that obtaining good balance was impossible. In neither case, however, does a direct causal link to electoral outcomes seem likely.

\footnotetext{
${ }^{14}$ One potential drawback to this initial control group, which consists largely of rejected applicants, is that unobserved causes of rejection (e.g., political bias or a politician's incompetence) might also influence election results. As a robustness check, we also reran the analysis using two different initial control groups that eliminate the 907 candidates who applied before the election and were rejected; they are replaced with several other categories of candidates. More details on these alternate control groups, as well as balance statistics and results, are in the online appendix. We obtained comparable balance on nearly all covariates. Estimated effects were significant and slightly larger, except for the effect on probability of reelection for one of the two control groups.
}

In contrast to features of the application itself, numerous characteristics of the candidate and municipality seem likely to affect both treatment assignment and the outcome. At the municipal level, these include geographical location as well as socioeconomic and political variables. We thus match on latitude, longitude, and dummy variables for the large states of Minas Gerais, São Paulo, and Rio Grande do Sul; municipal-level socioeconomic indicators such as Gini coefficient and Human Development Index (HDI); and political variables like size of the electorate and vote share for major parties (PT and $\mathrm{PSDB}$ ) in prior elections. At the individual level, we condition on a series of political covariates, including incumbency status, political party, election year, vote share of the candidate's current party in the last election, an indicator for whether the candidate ran in the last election, and for rerunners, personal vote share in the last election. Finally, we match on a set of individual socioeconomic characteristics, including occupation, education, and reported assets, that may influence both the success of the application and the candidate's electoral fortunes. ${ }^{15}$

The nonparametric matching procedure we use is genetic matching, which algorithmically maximizes balance across treatment and control units on observed covariates (Sekhon 2011). ${ }^{16}$ Matching is one-to-one (with replacement) and the estimand is the "average treatment effect on the treated," i.e., the treatment effect for those politicians who received a broadcasting license before the start of the campaign. The reported standard errors are those proposed by Abadie and Imbens (2006) for matching estimates with a fixed number of matches.

Balance before and after matching is reported in Table 3. "Standardized difference" is the mean difference between treatment and control, divided by the standard deviation of the variable in the treatment group, multiplied by 100 . In addition to standardized differences, we report p-values from paired t-tests under the null hypothesis of equality of means, as well as pvalues from Kolmogorov-Smirnov tests of equality of distributions (only for nonbinary variables). Before matching, the largest imbalance was in the total number of license requests from the municipality in response to a call for applications, with a standardized difference of -111 . The next largest imbalance was -27 , for a dummy variable for the state of Rio Grande do Sul. Overall, there

\footnotetext{
${ }^{15}$ The total value of reported assets was only available for candidates in the 2008 election.

${ }^{16}$ The balance metric maximized by the genetic matching algorithm is the lowest $\mathrm{p}$-value from paired t-tests of equality of means and KS tests of equality of distributions.
} 
TABLE 3 Balance Statistics Before and After Matching

\begin{tabular}{|c|c|c|c|c|c|c|}
\hline \multirow[b]{2}{*}{ Variable } & \multicolumn{2}{|c|}{$\begin{array}{l}\text { Standardized } \\
\text { Difference }\end{array}$} & \multicolumn{2}{|c|}{ T-test p-Value } & \multicolumn{2}{|c|}{ KS test p-Value } \\
\hline & $\begin{array}{c}\text { Before } \\
\text { Matching }\end{array}$ & $\begin{array}{c}\text { After } \\
\text { Matching }\end{array}$ & $\begin{array}{c}\text { Before } \\
\text { Matching }\end{array}$ & $\begin{array}{c}\text { After } \\
\text { Matching }\end{array}$ & $\begin{array}{c}\text { Before } \\
\text { Matching }\end{array}$ & $\begin{array}{c}\text { After } \\
\text { Matching }\end{array}$ \\
\hline Log Number of Applications & -111 & -1.3 & 0 & 0.13 & 0 & 0.93 \\
\hline State: Rio Grande do Sul & -27 & 0 & 0.00028 & 1 & & \\
\hline PT Pres. Vote Share (1998) & -23 & -0.8 & 0.00078 & 0.9 & 0.001 & 0.44 \\
\hline Election Year & 17 & 6 & 0.0073 & 0.21 & & \\
\hline Occupation: Media & 17 & 9.1 & 0.0055 & 0.19 & & \\
\hline Total Assets & 17 & 3.7 & 0.0087 & 0.46 & 0.008 & 0.071 \\
\hline Male & 16 & 6.1 & 0.017 & 0.48 & & \\
\hline Log Electorate & -14 & 9.3 & 0.029 & 0.11 & 0.006 & 0.78 \\
\hline PT Mayor Vote Share (2000) & -12 & -0.74 & 0.06 & 0.92 & 0.094 & 0.76 \\
\hline Occupation: Blue Collar & -12 & 1.3 & 0.073 & 0.71 & & \\
\hline PSDB Mayor Vote Share (2000) & -11 & 2 & 0.09 & 0.72 & 0.11 & 0.53 \\
\hline Prior Vote Share & 11 & 7.7 & 0.079 & 0.11 & 0.16 & 0.57 \\
\hline Occupation: White Collar & 9.8 & -3.5 & 0.12 & 0.37 & & \\
\hline State: Minas Gerais & 9 & 0 & 0.15 & 1 & & \\
\hline Education: Some Superior or More & -8.6 & -8.3 & 0.18 & 0.25 & & \\
\hline Party: PT & -8.6 & -0.92 & 0.19 & 0.65 & & \\
\hline GDP per Capita (2000) & -8.2 & 8 & 0.21 & 0.11 & 0.2 & 0.55 \\
\hline State: Bahia & 7.5 & -5.4 & 0.23 & 0.48 & & \\
\hline Occupation: None & -6.9 & 5.2 & 0.3 & 0.18 & & \\
\hline HDI (2000) & -6.1 & 6.6 & 0.34 & 0.14 & 0.099 & 0.53 \\
\hline Party: PMDB & -5.5 & -6.6 & 0.4 & 0.13 & & \\
\hline Incumbency & 5 & 2.4 & 0.43 & 0.68 & & \\
\hline Party: PSDB & 4.9 & 3.9 & 0.44 & 0.16 & & \\
\hline Party: PFL & -4 & 3 & 0.54 & 0.16 & & \\
\hline Latitude & -3.6 & -2.4 & 0.59 & 0.6 & 0.049 & 0.47 \\
\hline Year of Birth & -3.1 & -5 & 0.63 & 0.37 & 0.21 & 0.1 \\
\hline Party Prior Vote Share & 3 & 6.3 & 0.64 & 0.17 & 0.36 & 0.38 \\
\hline Occupation: Politician & -2.5 & 1.4 & 0.69 & 0.32 & & \\
\hline 2000 Gini & -2.4 & 1.3 & 0.71 & 0.86 & 0.45 & 0.24 \\
\hline Occupation: Education & -2 & 2.3 & 0.76 & 0.53 & & \\
\hline Ran Previously & -1.7 & 0.64 & 0.79 & 0.91 & & \\
\hline State: São Paulo & -1.7 & -2.9 & 0.8 & 0.44 & & \\
\hline Occupation: Government & -1.3 & 4.8 & 0.84 & 0.17 & & \\
\hline Occupation: Other & 1 & 3.4 & 0.88 & 0.51 & & \\
\hline Longitude & -0.41 & -7.6 & 0.95 & 0.12 & 0.83 & 0.15 \\
\hline
\end{tabular}

Note: Standardized difference is the mean difference divided by the standard deviation of the treatment units, multiplied by 100 . The p-values are from t-tests (two-sample before matching, paired after matching) and, for nonbinary variables, bootstrapped Kolmogorov-Smirnov tests.

are 14 variables before matching with p-values less than .1 or standardized differences larger than 10 .

After matching, the standardized difference on all variables is smaller than 10 , and nearly all $\mathrm{p}$-values are greater than 0.1 ; the only exception is the log of candidate assets with a KS test p-value of 0.07. Residual imbalance in this covariate is substantively small: the unlogged mean difference is 41 Brazilian reais (about 24 U.S. dollars). As an additional robustness check, we used postmatching regression, as recommended by Rubin (1979), to adjust 


\section{TABLE 4 The Effect of Community Radio} Control on Electoral Outcomes

\begin{tabular}{ccc}
\hline & Pct. Valid. Votes & Elected \\
\hline ATT Estimate & $0.39^{*}$ & $0.068 \dagger$ \\
SE & 0.17 & 0.039 \\
$n$ & 622 & 622 \\
\hline
\end{tabular}

${ }^{\dagger} \mathrm{p}<0.1 ;{ }^{*} \mathrm{p}<.05$.

for any residual imbalance in this covariate; our estimates (reported in the online appendix) were unchanged.

\section{Results}

According to our analysis, acquiring a community radio license prior to a municipal election campaign substantially boosts a candidate's vote share and probability of victory. Estimates of the ATT for both of these outcomes can be found in Table 4. Candidates whose licenses are approved before the campaign can expect to see their share of the valid vote increase by .39 percentage points (statistically significant at the $5 \%$ level), and their probability of being elected goes up by 068 (statistically significant at the $10 \%$ level). While these estimates might seem small in absolute terms, they are quite large when one considers how few votes city council members normally receive and how unlikely they are to get elected. Mean valid vote share in the matched control group is $2.36 \%$, and probability of election is 0.24 , so our effect estimates represent a $17 \%$ increase in vote share and a $28 \%$ increase in one's chances of winning when compared to similar candidates who did not receive a radio license.

\section{Conclusion}

As a spoil of office acquired through political bargaining, and a resource that helps politicians win future electoral contests, control of local media is a worrisome feature of modern Brazilian democracy. In contrast to egregious cases of national executives dominating the airwaves, the political manipulation of community radio has a tendency to fly under the radar screen. Consequently, it may be more difficult to stamp out. Judicial inquiries unraveled Alberto Fujimori's web of media control in Peru, and political pressures recently forced Chilean president Sebastián Piñera to sell his wholly owned television station, but political control of local media in Brazil has continued unabated for decades. Rather than an authoritarian holdover that might be expected to disappear with complete democratization, political control of local media in
Brazil is part and parcel of the democratic system. Yet this phenomenon seriously impinges upon the quality of Brazilian democracy by reducing vertical accountability, distorting citizens' preferences, and tilting the electoral playing field in favor of the powers that be.

This study confirms existing claims about the political control of media in Brazil and its effects on electoral outcomes, but it does so in a manner that more convincingly rules out alternative explanations. Control of Brazil's broadcast media by politicians is typically attributed to the backroom deals they are able to strike with federal officials, and the electoral success of politicians with broadcasting concessions is often considered a direct effect of their dominating the airwaves (Lima and Lopes 2007; Motter 1994). Yet existing studies cannot rule out other explanations for these patterns. Politicians' superior understanding of the bureaucratic approval process might help them craft applications that are more likely to be approved on their own merits, and those who gain broadcasting concessions might tend to be reelected because of superior campaigning skills rather than media control per se. Through the use of a regression discontinuity design to study the effect of incumbency on media control, and a matching analysis to examine the effect of media control on electoral outcomes, we are able to eliminate or largely rule out confounders such as these. Our causal estimates should lend confidence to the claims that holding public office helps politicians gain control of the media, and media control helps politicians win votes.

Though our analysis of incumbency, media control, and electoral outcomes focuses on municipal-level politicians and limited-range broadcasters, it has implications for higher-level offices and more powerful media as well. The same federal regulators who approve community radio applications also decide the fate of other broadcast media in Brazil, so incumbents may have been similarly favored in other instances where media control was parceled out to political bosses at the state level. The factors facilitating individual media effects at the municipal level—weak partisan cues, few alternative sources of political information, and high informational demands on voters-also apply more generally in Brazil (Baker, Ames, and Renno 2006; Boas 2005). Moreover, the same electoral system is used for state and federal deputy elections. Gaining control of a regional broadcaster might well confer the same sort of electoral benefits as community radio, but on a larger scale.

While previous studies of the effects of incumbency have focused on wealth accumulation, this article highlights the importance of nonmonetary spoils of office, which may be more likely to advance a politician's career and less likely to imperil it. Stealing from public 
coffers or lining one's pockets with bribe money may carry the seeds of their own destruction, at least for individual politicians. On average, these activities should undermine public support, reduce reelection prospects, and raise the risk of impeachment or judicial sanction. Media control, by contrast, should tend to boost one's future electability. In Brazil, many an elected official has been brought down by corruption charges, but few have hurt their political careers by amassing media empires.

Finally, the findings of this study have implications for research on incumbency advantage. In part because of the widespread tendency toward rent seeking in office, several studies have identified an overall incumbency disadvantage in new democracies, including Brazil (Linden 2004; Miguel and Zaidi 2003; Titiunik 2009; Uppal 2007). But incumbents who are able to gain political control of local media may be able to buck this trend, generating positive coverage that favors their future reelection. Such a spoil of office, if harnessed for campaign purposes, is likely to trump the electoral effects of mere perquisites such as newsworthiness or opportunities for constituent service. As scholars begin to examine incumbency effects on reelection in contexts with much weaker rule of law than the United States, it is important to pay attention to the ill-gotten advantages that may accrue to some officeholders in addition to the legitimate perks available to all.

\section{References}

Abadie, A., and G. W. Imbens. 2006. "Large Sample Properties of Matching Estimators for Average Treatment Effects." Econometrica 74(1): 235-67.

Acemoglu, Daron, María Angélica Bautista, Pablo Querubín, and James A. Robinson. 2008. "Economic and Political Inequality in Development: The Case of Cundinamarca, Colombia." In Institutions and Economic Performance, ed. Elhanan Helpman. Cambridge, MA: Harvard University Press, 181-245.

Ames, Barry. 1994. “The Reverse Coattails Effect: Local Party Organization in the 1989 Brazilian Presidential Election." American Political Science Review 88(1): 95-111.

Ames, Barry. 2001. The Deadlock of Democracy in Brazil. Ann Arbor: University of Michigan Press.

Ansolabehere, Stephen, Erik C. Snowberg, and James M. Snyder Jr. 2006. "Television and the Incumbency Advantage in U.S. Elections.” Legislative Studies Quarterly 31(4): 469-90.

Ansolabehere, Stephen, James M. Snyder, Jr., and Charles Stewart III. 2000. "Old Voters, New Voters, and the Personal Vote: Using Redistricting to Measure the Incumbency Advantage." American Journal of Political Science 44(1): 17-34.

Baker, Andy, Barry Ames, and Lucio R. Renno. 2006. “Social Context and Campaign Volatility in New Democracies: Networks and Neighborhoods in Brazil's 2002 Elections." American Journal of Political Science 50(2): 382-99.
Boas, Taylor C. 2005. "Television and Neopopulism in Latin America: Media Effects in Brazil and Peru." Latin American Research Review 40(2): 27-49.

Coppedge, Michael, and Wolfgang H. Reinicke. 1990. "Measuring Polyarchy." Studies in Comparative International Development 25(1): 51-72.

Cox, Gary W., and Jonathan M. Katz. 1996. "Why Did the Incumbency Advantage in U.S. House Elections Grow?” American Journal of Political Science 40(2): 478-97.

Desposato, Scott. 2004. "Going Negative in Comparative Perspective: Electoral Rules and Campaign Strategies." Presented at the annual meeting of the American Political Science Association, Chicago.

Desposato, Scott W. 2006. "Parties for Rent? Ambition, Ideology, and Party Switching in Brazil's Chamber of Deputies." American Journal of Political Science 50(1): 62-80.

Desposato, Scott. 2007. "Reforma política brasileira: O que precisa ser consertado, o que não precisa e o que fazer." In Instituições Representativas no Brasil: Balanço e Reforma, ed. Jairo Nicolau and Timothy Powers. Belo Horizonte: Editora UFMG, 123-53.

Diamond, Larry, and Leonardo Morlino, eds. 2005. Assessing the Quality of Democracy. Baltimore: Johns Hopkins University Press.

Eggers, Andrew C., and Jens Hainmueller. 2009. "MPs for Sale? Returns to Office in Postwar British Politics." American Political Science Review 103(4): 513-33.

Erikson, Robert S. 1971. "The Advantage of Incumbency in Congressional Elections.” Polity 3(3): 395-405.

Ferreira, Gisele, and Sayeg Nunes. 2006. "Radiodifusão e governabilidade: Roosevelt, Vargas e a atuação dos políticos locais nas emissões comunitárias legalizadas da Região Noroeste do Estado de São Paulo." UNIrevista 1(3): 1-13.

Fiorina, Morris P. 1977. "The Case of the Vanishing Marginals: The Bureaucracy Did It." American Political Science Review 71(1): 177-81.

Imbens, Guido, and Thomas Lemieux. 2007. "Regression Discontinuity Designs: A Guide to Practice." Journal of Econometrics 142(2): 615-35.

Krehbiel, Keith, and John R. Wright. 1983. "The Incumbency Effect in Congressional Elections: A Test of Two Explanations." American Journal of Political Science 27(1): 14057.

Kuschnir, Karina, Leandro Piquet Carneiro, and Rogério Schmitt. 1998. "A campanha eleitoral na TV em eleições locais: Estratégias e resultados.” In Candidatos e candidaturas: Enredos de campanha eleitoral no Brasil, ed. Irlys Barreira and Moacir Palmeira. São Paulo: Annablume, 53-80.

Lawson, Chappell, and James A. McCann. 2005. "Television News, Mexico's 2000 Elections and Media Effects in Emerging Democracies." British Journal of Political Science 35: $1-30$.

Lee, David S. 2008. "Randomized Experiments from Nonrandom Selection in U.S. House Elections." Journal of Econometrics 142: 675-97.

Lenz, Gabriel S., and Kevin Lim. 2009. "Getting Rich(er) in Office? Corruption and Wealth Accumulation in Congress." Unpublished manuscript. Massachusetts Institute of Technology. 
Levitt, Steven D., and Catherine D. Wolfram. 1997. "Decomposing the Sources of Incumbency Advantage in the U.S. House." Legislative Studies Quarterly 22(1): 45-60.

Lima, Venício A. de, and Cristiano Aguiar Lopes. 2007. Coronelismo eletrônico de novo tipo (1999-2004). Brasília: Observatório da Imprensa/ProJor.

Linden, Leigh L. 2004. “Are Incumbents Really Advantaged? The Preference for Non-Incumbents in Indian National Elections." Unpublished manuscript. Massachusetts Institute of Technology.

Mayhew, David R. 1974. "Congressional Elections: The Case of the Vanishing Marginals.” Polity 6(3): 295-317.

McCrary, J. 2008. "Manipulation of the Running Variable in the Regression Discontinuity Design: A Density Test." Journal of Econometrics 142(2): 698-714.

Mick, Jacques, and Fabiana Vieira. 2003. "Política e religião nas radios comunitárias de SC." Paper presented at INTERCOM, Belo Horizonte, Brazil.

Miguel, Edward, and Farhan Zaidi. 2003. "Do Politicians Reward Their Supporters? Regression Discontinuity Evidence from Ghana." Unpublished manuscript. University of California, Berkeley.

Motter, Paulino. 1994. "O uso político das concessões das emissoras de rádio e televisão no governo Sarney." Comunicação \& Política 1(1): 89-116.

Nunes, Márcia Vidal. 2004. “As radios comunitárias nas campanhas eleitorais: Exercício da cidadania ou instrumentalização (1998-2000)." Revista de Sociologia e Política 22: 59-76.

Prior, Markus. 2006. "The Incumbent in the Living Room: The Rise of Television and the Incumbency Advantage in U.S. House Elections." Journal of Politics 68(3): 657-73.

Querubin, Pablo, and James M. Snyder Jr. 2009. "The Returns to U.S. Congressional Seats in the Mid-19th Century." In The Political Economy of Democracy, ed. Enriqueta Aragonès, Carmen Beviá, Humberto Llavador, and Norman Schofield. Bilbao, Spain: Fundación BBVA, 225-40.

Rosenbaum, P. R. 1984. "The Consequences of Adjustment for a Concomitant Variable That Has Been Affected by the Treatment." Journal of the Royal Statistical Society. Series A (General) 147(5): 656-66.

Rubin, D. B. 1979. "Using Multivariate Matched Sampling and Regression Adjustment to Control Bias in Observational Studies." Journal of the American Statistical Association 74(366): 318-28.

Scinocca, Ana Paula, and Eugênia Lopes. 2010. "Políticos viram despachantes de luxo e apadrinham rádios comunitárias." $O$ Estado de São Paulo. March 15.

Sekhon, Jasjeet. 2011. "Multivariate and Propensity Score Matching Software with Automated Balance Optimization: The Matching Package for R." Journal of Statistical Software 42(7): 1-52.

Titiunik, Rocío. 2009. "Incumbency Advantage in Brazil: Evidence from Municipal Mayoral Elections.” Unpublished manuscript. University of Michigan.

Uppal, Yogesh. 2007. "The Disadvantaged Incumbents: Estimating Incumbency Effects in Indian State Legislatures." Munich Personal RePEc Archive Paper No. 8515.

\section{Supporting Information}

Additional Supporting Information may be found in the online version of this article:

Table A1: Effect of Incumbency: Descriptive Statistics

Table A2: Effect of Radio Control: Descriptive Statistics Table A3: Alternative Forcing Variable Results: Vote Margin as a Share of Valid Votes (see endnote 11). Balance Statistics for Four Different Specifications. Heteroskedasticity-consistent standard errors in parentheses.

Table A4: Alternative Forcing Variable Results: Vote Margin as a Share of Valid Votes (see endnote 11). Does incumbency affect the likelihood of application approval or rejection? The estimated local average treatment effect of winning office on having a community radio license application approved or rejected, under four different specifications. Standard errors are heteroskedasticityconsistent.

Table A5: Alternative Forcing Variable Results: Inflated Vote Margin (see endnote 11). Balance Statistics for Four Different Specifications. Heteroskedasticityconsistent standard errors in parentheses.

Table A6: Alternative Forcing Variable Results: Inflated Vote Margin (see endnote 11). Does incumbency affect the likelihood of application approval or rejection? The estimated local average treatment effect of winning office on having a community radio license application approved or rejected, under four different specifications. Standard errors are heteroskedasticity-consistent.

Table A7: Heterogeneity by Population in the Effect of Incumbency on Application Approval and Rejection, using Alternative Forcing Variable (Vote Margin as a Share of Valid Votes). The estimated local average treatment effect of winning office on having a community radio license application approved or rejected, under four different specifications, with sample split by median population of municipalities with community radio stations $(14,149)$. Standard errors are heteroskedasticity-consistent.

Table A8: Heterogeneity by Population in the Effect of Incumbency on Application Approval and Rejection. The estimated local average treatment effect of winning office on having a community radio license application approved or rejected, under four different specifications, with sample split by median population of municipalities with community radio stations $(14,149)$. Standard errors are heteroskedasticity-consistent.

Table A9: Matching with Covariate Adjustment and Two Alternate Control Groups. ATT estimates for the effect of obtaining a community radio license on electoral 
outcomes. Covariate adjustment uses the log of the value of the candidate's assets.

Table A10: Balance Statistics before and after matching using the first alternate control group. Standardized difference is the mean difference divided by the standard deviation of the treatment units, multiplied by 100. p-values are from t-tests (two-sample before matching, paired after matching) and, for non-binary variables, bootstrapped Kolmogorov-Smirnov tests.

Table A11: Balance Statistics before and after matching using the second alternate control group. Standardized difference is the mean difference divided by the standard deviation of the treatment units, multiplied by 100 . p-values are from t-tests (two-sample before matching, paired after matching) and, for non-binary variables, bootstrapped Kolmogorov-Smirnov tests.

Please note: Wiley-Blackwell is not responsible for the content or functionality of any supporting materials supplied by the authors. Any queries (other than missing material) should be directed to the corresponding author for the article. 